\title{
METODE PENDIDIKAN KEBERAGAMAAN DI LINGKUNGAN KELUARGA
}

\author{
Sadari \\ Institut Agama Islam Shalahuddin Al-Ayyubi (INISA) \\ Tambun-Bekasi \\ arifahmikhan@gmail.com
}

\begin{abstract}
Abstrak
Pelaksanaan pendidikan Agama Islam, Bagi anak di dalam lingkungan keluarga sangat penting untuk diperhatikan oleh orang tua, kewajiban itu terpikul dipundak kedua orang tua. Sangat tidak benar seandainya orang tua menyerahkan pendidikan Agama bagi anakanaknya kepada sekolah. Karena pembinaan keberagamaan anak akan lebih banyak berada di dalam keluarga dan itu membutuhkan pengawasan langsung dari orang tua. Orang tua perlu menambah ilmu pengetahuan agamanya sehingga memiliki modal untuk dapat memberikan pendidikan keagamaan kepada anak-anaknya. Materi pokok pendidikan Agama Islam yang harus ditanamkan (dididikkan) kepada anak-anak di dalam lingkungan keluarga terdapat pada Q.S Luqman ayat 13-19. Faktor-fakior yang mungkin dapat menghambat pelaksanaan pendidikan Agama Islam bagi anak di lingkungan keluarga adalah faktor pendidik (orang tua sendiri), anak didik (dalam hal ini anak) dan lingkungan dimana anak berada.

Metode-metode yang dipakai dalam pelaksanaan pendidikan agama Islam di lingkungan keluarga. Metode-metode pendidikan Islam yang dapat dipakai di dalam menyampaikan materi-materi tersebut di atas adalah mauizah al-hasanah (pemberian nasehat yang baik), kasih sayang, perumpamaan, pembiasaan dan keteladanan. Namun demikian bukan berarti metode yang lainnya tidak bisa diterapkan. Penggunaan metode tergantung situasi dan kondisi orang tua dalam menyampaikan materi keagamaan.
\end{abstract}

Kata Kunci : Metode Pendidikan; Keberagamaan; Keluarga 


\section{A. Pendahuluan}

Kehidupan manusia pada masa kini diwarnai dengan kemajuan dalam berbagai manusia kepada taraf kehidupan yang relatif lebih maju. Hal ini merupakan keberhasilan manusia dalam rangka mengembangkan dirinya untuk mendapatkan kebahagiaan dalam kehidupan ini. keberhasilan manusia dalam bidang ini patut kita banggakan, karena sedikit banyak hasil-hasilnya dapat kita rasakan bersama di tengah-tengah kehidupan manusia di abad modem ini, masih ada satu hal yang sangat memprihatinkan yaitu terjadinya dekadensi moral (akhlak) baik di kalangan anak muda maupun orang dewasa.

Kehidupan mereka seakan-akan tidak lagi dilandasi oleh nilai-nilai akhlak yang luhur, mereka hidup dengan menuruti hawa nafsunya. Sebagai contoh, korupsi, pergaulan bebas dan suasana tidak menyenangkan dalam keluarga dengan cepat akan diserap oleh anak, seperti kesibukan orang tua dalam mencari nafkaah. Kesibukan orang-orang tua dalam mencari nafkah untuk mempertahankan kelangsungan hidup keluarganya dan ketentuan mereka dalam meningkatkan kekayaan materinya pada akhirakhir ini melengahkan mereka dan kesadaran akan pentingnya nilai-nilai bagi generasi keturunannya.

Kemajuan ilmu pengetahuan dan teknologi saja ternyata tidak menjamin membawa manusia kepada kehidupan yang berakhlak mulia, bahkan malah bisa membawa kepada kerusakan akhlak manusia. Keadaan seperti di atas perlu sekali mendapat perhalian dari sebagian manusia guna meluruskan dan membina mereka dan kehidupan yang mnyimpang, kepada kehidupan yang dilandasi dengan nilai-nilai agama dan akhlak mulia.

Kemerosotan akhlak pada suatu generasi akan sangat mempengaruhi dan membawa dampak negatif kepada generasi berikutnya. Untuk mencegah terjadinya hal ini, perlu diadakan usaha-usaha preventif yang dilaksanakan oleh segenap pendidik, khususnya para orang tua.

\section{B. Pengertian Metode Pendidikan}

Secara bahasa metode berasal dari dua kata yaitu meta dan hodos. Meta berarti "melalui." Dan hodos berarti "jalan atau cara", bila ditambah logi sehingga menjadi metodologi berarti "ilmu pengetahuan tentang jalan atau cara yang harus dilalui untuk mencapai tujuan", oleh karena kata logi yang berasal dari kata Yunani (Greek) logos berarti "akal" atau "ilmu". 
Sedangkan secara istilah, Edgar Bruce Wesley mendefinisikan metode dalam bidang pendidikan sebagai: "rentetan kegiatan terarah bagi guru yang menyebabkan timbulnya proses belajar pada murid-murid, atau ia adalah proses yang melaksanakannya yang sempurma menghasilkan proses belajar, atau ia adalah jalan yang dengannya pengajaran itu menjadi berkesan." Disisi lain Imam Barnadib mengartikan metode sebagai suatu sarana untuk menemukan, menguji dan menyusun data yang diperlukan bagi pengembangan pendidikan.

Dengan demikian secara umum metode adalah cara untuk mencapai sebuah tujuan dengan jalan yang sudah ditentukan, dalam metode pendidikan dapat diartikan sebagai cara untuk mencapai tujuan pendidikan sesuai kurikulum yang ditentukan. Apabila ditarik pada pendidikan Islam, metode dapat diartikan sebagai jalan untuk menanamkan pengetahuan agama pada diri seseorang sehingga terlihat dalam pribadi obyek sasaran, yaitu pribadi Islami.

Adapun al-Quran sendiri secara eksplisit tidak menjelaskan arti dan metode pendidikan, namun kata metode dalam bahasa Arab dibahasakan dengan kata al-Tariqah. Banyak dijumpai dalam al-Qur'an, Menurut Muhammad Abd al-Baqi, di dalam al-Qur'an kata al-Tariqah diulang sebanyak sembilan kali. Salah satunya kata ini terkadang dihubungkan dengan sifat dari jalan tersebut, seperti al-tariqah al-mustaqimah, yang diartikan jalan yang lurus. Hal ini terdapat dalam al-Qur'an sural al-Ahqaf ayat 30

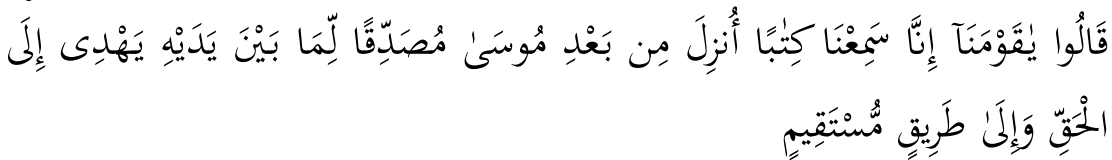

Artinya : "Mereka berkata, hai kaum kami, sesungguhnya kami Telah mendengarkan Kitab (al-Qur'an) yang Telah diturunkan sesudah Musa yang membenarkan kitab-kitab yang sebelumnya lagi memimpm kepada kebenaran dan kepada jalan yang lurus."

Dari ayat di atas dapat dijelaskan bahwa metode atau jalan oleh al-Qur'an dilihat dari sudut objeknya, fungsinya, akibatnya, dan sebagainya. Ini dapat diartikan bahwa perhatian al-Qur'an terhadap metode demikian tinggi, dengan demikian al-Qur'an lebih menunjukkan isyarat-isyarat yang memungkinkan metode ini berkembang lebih lanjut.

Dengan berlandaskan pada beberapa definitif di atas dapat ditegaskan bahwa metode pendidikan merupakan sebuah 
mediator yang mengolah dan mengembangkan suatu gagasan sehingga menghasilkan suatu teori atau temuan untuk menyampaikan sebuah visi pendidikan kepada tujuannya.

\section{Metode Pendidikan Keberagaan di Lingkungan}

Sarana untuk membentuk keluarga dalam Islam harus melalui ikatan pernikahan. Dengan melangsungkan pernikahan, maka pasangan suami-istri akan memperoleh manfaat dari pernikahan tersebut. Salah satu manfaatnya adalah memelihara kelangsungan jenis manusia di dunia yang fana ini. Kelahiran anak merupakan amanat dan Allah Swt kepada bapak dan ibu sebagai pemegang amanat yang harusnya dijaga, dirawat, dan diberikan pendidikan. Itu semua merupakan bagian dari tanggung jawab orang tua kepada anaknya.

Anak dilahirkan tidak dalam keadaan lengkap dan tidak pula dalam keadaan kosong. Ia dilahirkan dalam keadaan fitrah. Memang ia dilahirkan dalam keadaan tidak tahu apa-apa, akan tetapi anak telah dibekali dengan pendengaran, penglihatan, dan kata hati. Dengan diberikannya penglihatan, pendengaran, dan kata hati tersebut, diharapkan orang tua harus mampu membimbing, mengarahkan, dan mendidiknya dengan ekstra hati-hati karena anak sebagai peniru yang ulung.

Oleh karena itu semaksimal mungkin orang tua memberikan pelayanan terhadap anaknya. Pelayanan yang maksimal akan menghasilkan suatu harapan bagi bapak ibunya, tiada lain suatu kebahagiaan hasil jerih payahnya. Sebab anak adalah sumber kebahagiaan, kesenangan, dan sebagai harapan dimasa yang akan datang. Harapan-harapan orang tua akan terwujud tatkala mereka mempersiapkan sedini mungkin pendidikan yang baik sebagai sarana pertumbuhan dan perkembangan bagi anak.

Memang diakui bahwa mengemudikan bahtera rumah tangga yang baik, yang sakinah, dan yang maslahah merupakan tugas kewajiban yang sangat rumit, tidak kalah minimnya dengan mengelola sebuah pabrik dan tidak kalah canggihnya dengan mengemudikan pesawat terbang karena orang tua harus siap untuk memperpadukan sekian banyak unsur dan dimensi mulai dan dimensi sikap mental, ilmu pengetahuan, ketrampilan dan lain sebagainya. Sebagai kewajiban dari orang tua, dalam hal ini adalah pemegang amanat, maka barang siapa yang mampu menjaga amanat tersebut akan diberi pahala, dan sebaliknya. 
Dalam mendidik anak, tentunya harus ada kesepakatan antara bapak ibu sebagai orang tua, akan dibawa kepada pendidikan yang otoriter atau pendidikan yang demokratis atau bahkan yang liberal, sebab mereka penentu pelaksana dalam keluarga. Dalam kehidupan masyarakat terkecil, yaitu keluarga, suami secara fungsional adalah penanggung jawab utama rumah tangga (keluarga) sedangkan istri adalah mitra setia yang aktif konstruktif mengelola rumah tangga. Operasionalisasi kehidupan berkeluarga sebaiknya dilakukan berdasarkan amar makruf nahi munkar.

\section{Metode Komunikasi Orang Tua terhadap Anak}

Sekitar dua puluh menit pertama kuliah psikiatri, biasanya dosen memberi kesempatan untuk mewawancarai pasien gangguan jiwa yang dihadirkan di depan kelas. Ini sangat penting bagi mahasiswa agar bisa memahami isi perkuliahan dengan lebih baik, sehingga nantinya ia bisa lebih mudah mengenali simptomsimptom ${ }^{1}$ gangguan jiwa sebagai bekal untuk menentukan jenis gangguan jiwa yang dialami dan bentuk terapi yang harus diberikan.

Menurut pandangan psikologi, gangguan jiwa tidak datang tiba-tiba. Ia merupakan hasil dari proses hidup yang panjang. Apa yang sering disebut sebagai penyebab terjadinya gangguan jiwa sebenarnya hanya merupakan peristiwa pemicu.

Ibarat meniup balon anak-anak sampai menggelembung keras sekali, begitu berbenturan dengan ranting pohon sedikit saja sudah menyebabkan balon meletus. Apa yang menyebabkan balon itu meletus? Bukan terbenturnya ia dengan ranting pohon, tetapi tiupan yang menjadikan balon menggelembung sedemikian besar dan keras. Benturan dengan ranting hanya peristiwa pemicu. Jadi, tidak ada orang gila karena putus cinta. Juga tidak ada orang yang harus menjadi gila karena kehilangan jabatan, yang ada adalah orang dengan keadaan jiwa yang sudah rapuh, sudah rawan, struktur mentalnya sudah kurang bagus dan kemudian mengalami peristiwa yang mengguncangkan sebagai pemicu munculnya gangguan jiwa.

Persoalannya, apa yang menyebabkan seseorang memiliki jiwa yang rapuh? Apakah karena mereka banyak menghadapi pengalaman-pengalaman pahit? Apakah karena mereka sering

\footnotetext{
${ }^{1}$ Simptom adalah gejala yang nampak.
} 
dihadapkan pada kegagalan demi kegagalan? Ataukah, mereka memang memiliki mental bawaan yang labil?

Sebagian besar pelaku bunuh diri adalah perempuan yang memiliki sifat manja. Tidak demikian persoalannya, banyak orang yang sering mengalami kegagalan, ditimpa berbagai pengalaman pahit, serta mengalami kegetiran demi kegetiran. Akan tetapi mereka mampu menjadi manusia yang besar dan membawa kebaikan bagi umat manusia sepanjang sejarah. Tidak jarang orang merasa bersyukur dengan pengalaman masa lalunya yang sulit karena dianggapnya sebagai proses penempaan diri yang bagus. Sebaliknya, orang-orang yang pengalamannya manis-manis saja, harus terjungkal begitu menemui persoalan yang tak seberapa besar.

Perbedaan yang tangguh dan yang rapuh adalah pada penghayatan mereka terhadap peristiwa yang dialami. Lantaran artikel ini bukan membicarakan kesehatan mental, maka hanya untuk mengajak melihatnya dari sisi pendidikan anak, khususnya bagaimana komunikasi dalam sehari-hari mempengaruhi pendidikan anak.

Sebelum berbicara lebih jauh, cerita berikut sebaiknya di simak. Prof. Dr. dr. Hernomo Ontoseno Koesoemobroto, Kabag SPK (Sentra Pengobatan Keracunan) IRD RSUD dr. Soetomo Surabaya mengungkapkan hasil sebuah penelitian yang dilakukan oleh lembaga yang dipimpinnya. Menurut Hernomo, sebagian besar pelaku bunuh diri yang dikirimkan ke IRD SPK adalah perempuan yang memiliki sifat manja (ngaleman dalam bahasa Jawa). Artinya, pada masa hidupnya mereka itu sangat manja kepada orangtuanya, terutama kepada ibunya.

Menurutnya "Untuk itu, ibu-ibu yang memiliki anak perempuan aleman memang harus memperlakukannya ekstra hati-hati," kata Hernomo sebagaimana diberitakan oleh harian Jawa Pos, 23 Januari 1998. Apa yang menyebabkan anak manja? Banyak yang salah paham. Manja sering dihubungkan dengan kasih-sayang berlebihan, sehingga membuat para orangtua berhati-hati dalam memberikan kasih-sayang (untuk tidak menyebut kurang sayang).

Mereka bersikap keras pada anak, padahal sikap keras ini bisa menyebabkan mental anak kurang kokoh. Manja sebenarnya tidak berhubungan dengan banyak sedikitnya kasih-sayang yang diterima anak. Al-Hasan dan Al-Husain adalah anak yang banyak memperoleh kasih-sayang, dari orangtua maupun kakeknya Muhammad shallallahu 'alaihi wasallam. Tidak ada orang yang 
menyayangi anak seperti Rasulullah, sampai harus merangkak kuda-kudaan dengan anak, menjulurkan lidah untuk bercanda ataupun memanjangkan sujud demi kenyamanan cucunya ketika menaiki lehernya di saat bersujud. Tetapi kita semua melihat, mereka berdua tidak menjadi pribadi yang manja. Bahkan sebaliknya mereka menjadi pahlawan-pahlawan yang rela ditebas lehernya dengan keharuman syuhada. Mereka tidak menjadi orang yang manja dan cengeng.

Ketika ada yang merenggut anak secara kasar dari gendongan Rasulullah karena pipis, Rasulullah bahkan menegur, "Pakaian yang basah ini dapat dibersihkan dengan air, tetapi apa yang dapat menghilangkan kekeruhan dalam jiwa anak akibat renggutanmu yang kasar?" Sepanjang yang saya ketahui, sikap manja lebih banyak berhubungan dengan komunikasi kepada anak. Secara sederhana, dapat membagi komunikasi ini ke dalam dua macam, yaitu komunikasi kepada anak dan komunikasi bersama anak.

Komunikasi kepada anak, maksudnya adalah bagaimana orangtua berbicara kepada anak, menyatakan maksud dan nasehat kepada anak, serta mendiskusikan sesuatu dengan anak. Termasuk dalam kategori komunikasi kepada anak antara lain menyuruh, melarang, menganjurkan, menceritakan sesuatu, serta bentuk-bentuk komunikasi lainnya yang secara langsung ditujukkan kepada anak dan diungkapkan secara langsung kepada anak. Tulisan dan seminar-seminar tentang komunikasi orangtua dan anak umumnya hanya membicarakan komunikasi jenis ini. Akibat peristiwa itu pun akhirnya berbeda-beda bagi tiap anak. Apa yang membedakan? Ungkapan spontan masing-masing orangtua.

Komunikasi bersama anak, maksudnya adalah segala bentuk perilaku komunikasi yang tidak ditujukan kepada anak, akan tetapi anak dapat menangkap dan mendengarnya. Kalau Anda berbicara dengan suami Anda dengan cara yang manja merajuk-rajuk dan anak melihat perilaku komunikasi Anda itu, maka anak menerimanya sebagai proses belajar dan secara otomatis ia mempersepsi apa yang ia lihat, dengar, dan rasa.

Artikel ini akan membicarakan lebih jauh masalah komunikasi bersama anak. Secara lebih khusus menyoroti apa pengaruhnya perilaku komunikasi suami-istri terhadap pendidikan anak. Sementara itu, berkenaan dengan masalah komunikasi kepada anak, bukan buku tentang pernikahan yang bertugas membahasnya. 
Kembali kepada kasus gadis manja, komunikasi orangtua banyak berperan menjadikan seorang anak memiliki sifat manja. Anak belajar melakukan identifikasi diri, tidak sekedar imitasi atau meniru-niru dari orangtua. Anak belajar menghayati peristiwa "dari bagaimana orangtua menghayati". Dalam hal ini, anak belajar dari ekspresi yang tampak. Ini terutama kelihatan pada komunikasi sehari-hari antara suami dan istri dan justru bukan pada komunikasi antara orangtua kepada anak.

Bukan merupakan sesuatu yang aneh jika istri berbicara dengan cara merajuk-rajuk manja. Bagi pengantin baru, ini menyenangkan. Segala keindahan rasanya bertabur menjadi satu ketika mendengar istri berkata manja. Tetapi hati-hatilah dalam menempatkan kemanjaan agar tidak tetap terbawa ketika anakanak telah lahir. Gaya bicara istri yang merajuk manja bisa membawa anak untuk cengeng dan manja.

Masih sejenis ini adalah respon ketika mengalami sesuatu; entah tersandung batu, entah digelitik suami, entah ketika udara begitu panas ataupun dingin; baik dalam suasana bercanda, serius, santai ataukah dalam suasana tegang. Kadangkala ketika udara terasa panas, begitu cepat mengatakan, "Aduuh, panas, Mas. Kenapa sih kok panas? Aduuh...!"

Dari sisi cara pengucapannya (sayang saya tidak bisa mencontohkan secara lisan) kalimat itu bisa membawa anak belajar cengeng dan manja. Dari sisi isi, kalimat-kalimat sejenis ini mendorong anak untuk mudah mengeluhkan cuaca yang jika pola itu dibawa terus bisa sampai kepada sikap mudah menyalahkan keadaan dan zaman (seperti yang kadang dilihat di sekeliling kita). Kalimat seperti itu juga merangsang anak tidak mensyukuri nikmat Allah dan menilai keadilan Ilahi dengan cara yang sedemikian dangkal. Hanya karena hawa dingin yang agak kuat, merasa Tuhan sedang "tidak berpihak kepada kita"; kita merasa Tuhan tidak mendengar do'a kita. Alangkah seringnya kita bertuhan dengan sikap yang kekanak-kanakan dan egois. Alangkah seringnya ini keminter (sok cerdas) di hadapan Allah, Tuhan Yang Maha Luas Pengetahuan-Nya. Allah telah mengabarkan: (QS. Al-Baqarah [2]: 29).

$$
\text { وَهُوَ بِكُلِّن شَنٍِْ عَلِيمُ }
$$

Artinya : "Maha sempurna pengetahuan-Nya tentang apa saja."

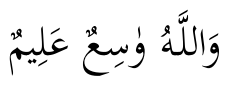


Artinya : "Dan Allah Maha Luas, Maha Tahu." (QS Ali 'Imran [3]: 73).

Ungkapan yang spontan tentang apa saja di sekeliling kita maupun ucapan-ucapan kepada suami, merupakan alat untuk bercermin bagi anak. Anak belajar menghayati hidup sehari-hari, memaknai rasa capek, ganjalan, dan berbagai bentuk kejadian sebagaimana ia mengidentifikasi dari orangtua, terutama ibu.

Artikel ini memberi contoh tentang ungkapan spontan ini. Sebagaimana ibu-ibu yang lain, anak mungkin pernah kehujanan dan kepanasan. Tetapi reaksi anak terhadap pengalaman kehujanan yang ia alami bisa berbeda seratus delapan puluh derajat dibanding anak-anak lain. Akibat dari peristiwa itu pun akhirnya berbeda-beda bagi tiap anak. Apa yang membedakan? Ungkapan spontan masing-masing orangtua, atau setidaknya ungkapan orangtua ketika mengalami peristiwa serupa.

Gaya bicara istri yang merajuk manja bisa membawa anak untuk cengeng dan manja. Sebagian orangtua merespon anak yang pulang dalam keadaan basah kuyup dengan ungkapan gembira. Bahkan sebagian ada yang bangga, "Lihat, dia datang. Dia memang punya semangat. Itu, anakmu!" Tetapi sebagian lainnya segera menyambut anak dengan sejumlah pertanyaan, secara langsung kepada anak maupun tidak. Orangtua berkata, "Aduh..., kenapa kamu basah kuyup begini? Tadi kan sudah kelihatan berawan, kenapa tidak membawa jas hujan atau payung. Coba kalau tadi bawa payung, kamu tidak sampai kehujanan seperti ini. Makanya, lain kali dengar kata Mama. Ini, kasihan sekali kamu. Pasti kamu kedinginan."

Atau, "Aduuh, Pak. Tadi kenapa Didin nggak disuruh bawa payung? Tuh, kasihan dia. Kedinginan pasti. Coba tadi kamu mau perhatian sedikit, dia nggak harus pulang dengan kehujanan begitu." Kalimat ini akan lebih "heroik" lagi kalau diteruskan hingga panjang sekali dan diucapkan berulang-ulang, bahkan ketika anak sudah tidak merasa kedinginan (secara fisik).

Meskipun kalimat ini mengekspresikan perasaan ibu yang khawatir terhadap anaknya karena besarnya perasaan sayang, tetapi efeknya bagi anak justru tidak menguatkan jiwa. Anak merasa tertekan oleh "kesalahan-kesalahannya" (apalagi jika Anda sebelumnya tidak mengingatkan untuk bawa payung) ${ }^{2}$ di saat dia masih merasa kedinginan.

\footnotetext{
${ }^{2}$ Kadang ibu tidak mengingatkan anak untuk membawa payung atau jas hujan ketika anak akan berangkat les, misalnya. Tetapi ketika melihat anak pulang dalam keadaan kehujanan, ia sibuk menanyai anak mengapa tadi tidak
} 
Anak belajar untuk mengasihani dirinya sendiri sehingga ia melatih dirinya untuk tidak berani menghadapi hujan dan tidak tahan terhadap "rintangan-rintangan kecil" yang ia jumpai, bahkan yang belum ia jumpai. Ia tidak bisa menjadi seorang Emha Ainun Nadjib "muda" yang suatu saat harus tergopohgopoh memberesi kertas yang akan dijualnya di saat hujan akan turun.

Ia tidak bisa menjadi seorang Imam Al-Ghazali yang ketika akan berguru disuruh gurunya untuk membuang kotoran kuda dengan tangannya sendiri. Ia tidak bisa menjadi pribadi cemerlang tanpa fasilitas (dimulai dari fasilitas payung). ${ }^{3}$

Ia hanya akan menjadi manusia biasa-biasa saja sebatas fasilitas yang sanggup ia dapatkan dari orangtua. Akibatnya, biaya mendidik akan sangat mahal. Ini berbeda dengan kalimat pertama. Pada kalimat pertama ungkapan rasa kasihan dari ibu tidak ditunjukkan dengan kata-kata kasihan, tetapi dengan katakata yang menunjukkan kegembiraan ibu melihat anaknya datang. Kalimat seperti ini memberikan efek yang lebih membesarkan hati dan menguatkan semangat. Apalagi kalau diikuti dengan tindakan memberikan handuk (tubuh yang basah dapat dikeringkan dengan handuk, bukan omelan), mengantarkannya ke kamar mandi, memberinya minuman hangat, dan menemaninya sambil mendengar cerita-cerita dari anak. Sikap seperti inilah yang menghangatkan jiwa anak.

Bukan kata-kata penyesalan dari lantaran anak tidak membawa payung atau jas hujan. Ada sebuah cerita anak kecil dengan kakeknya. "cucu sang kakek menghabiskan masa kecil bersama kakek sampai ia meninggal ketika itu kelas 1 SMP. Mereka tinggal di rumah yang bocor kalau hujan. Rumah-rumah lain juga banyak yang bocor.

Bedanya, ketika hujan datang, kami tidak menggerutu dan sedih sebagaimana yang kadang didengar dari orang-orang lain

membawa payung dan asyik menyalahkan suami lantaran tadi tidak menyuruh anak membawa payung. Sikap semacam ini memberi efek yang negatif bagi anak. Inilah yang disebut dengan argumentum ad hominem atau menyalahkan orang untuk membenarkan diri sendiri. Lebih jauh silakan lihat Salahnya Kodok: Bahagia Mendidik Anak bagi Ummahat (MitraPustaka, 1996).

${ }^{3}$ Sesungguhnya segala sesuatu yang ada di dunia ini, di sekeliling kita ini, adalah fasilitas bagi pencapaian kesempurnaan kita. Peristiwa hujan dan panas, air yang mengalir maupun angin yang berhembus, adalah fasilitas bagi kematangan jiwa anak dan latihan jiwa anak. Sesungguhnya setiap hal yang kita jumpai adalah pelajaran bagi orang-orang yang mengambil pelajaran. Mahasuci Allah dengan segala ciptaan-Nya. 
yang mempunyai pengalaman serupa. Hujan selalu disambut dengan penuh rasa syukur oleh almarhum kakek, setidaknya begitu yang diingat. Setelah memberesi apa yang perlu diberesi, kami biasa berkumpul bersama untuk menikmati makanan ringan yang digoreng nenek.

Pada saat seperti itu, kakek biasa menyitir ayat-ayat suci atau hadis yang menceritakan tentang nikmat Allah, tentang turunnya hujan yang akan menumbuhkan tanaman-tanaman, tentang mensyukuri nikmat, tentang surga, tentang kufur nikmat yang akan mengubah karunia menjadi malapetaka.

Allah Maha Kuasa mengubah hujan yang penuh kenikmatan menjadi malapetaka yang merobohkan pohon-pohon dan menghanyutkan rumah-rumah. Kadang pada saat hujan seperti itu, kakek tekun membaca kitab dan menceritakan isinya. Cerita tentang isi kitab sering seperti tidak ditujukan secara langsung kepada anak cucunya, tetapi dibaca sedemikian rupa sehingga kami mendengarnya. Atau, kakek berdialog dengan nenek tentang isi kitab.

Situasi semacam ini, yang melahirkan penghayatan tentang hujan sebagai nikmat dan saat-saat akrab, dirasakan amat besar manfaatnya. Kita tidak tergantung kepada suasana yang terang dan tenang untuk membaca. Saat-saat hujan deras tetap memberikan keasyikan untuk membaca, menulis, atau pun berdiskusi. Rintik hujan bukan halangan untuk pergi (dengan jalan kaki) demi memperoleh apa yang dibutuhkan, misalnya buku baru di toko.

Ada lagi manfaat-manfaat lain, khususnya bagi tumbuhnya semangat dan kemampuan menghayati panas dan dingin atau keadaan lain sebagai karunia Tuhan Yang Memberi Nikmat dengan adil. Begitu. Komunikasi sehari-hari mempengaruhi kematangan anak, mempengaruhi pendidikan anak. Komunikasi bersama anak ini mempengaruhi baik dari segi cara kita berkomunikasi maupun dari segi isi komunikasi. Jika peribahasa mengatakan bahasa menunjukkan bangsa, maka komunikasi menunjukkan "bagaimana kita" sehingga seperti itulah anak mengidentifikasi. Pengaruh ini tidak hanya secara khusus berkenaan konteks komunikasi.

Maksudnya, jika sering mengeluhkan hujan di saat akan pergi atau menjemur pakaian, maka pengaruhnya bagi anak tidak hanya terhadap perasaannya ketika hujan turun, tetapi meluas ke aspek-aspek lain. Bicara tentang pengaruh isi komunikasi bagi pendidikan anak, teringat dengan Murtadha Muthahhari. Ia 
pernah berkata: "Kita meratapi generasi ini disebabkan ia meninggalkan al-Qur'an".

Mengapa mereka tidak mempelajari al-Qur'an di sekolahsekolah mereka? Bahkan setelah memasuki perguruan tinggi, mereka tetap saja tidak mampu membaca al-Qur'an. Tak diragukan lagi, hal ini tentunya amat menyedihkan. Namun seharusnya bertanya kepada diri kita sendiri. "Apa kiranya yang telah dilakukan sampai sekarang mengenai hal ini? Apakah, dengan menyelenggarakan beberapa pelajaran fiqih dan cara membaca al-Qur'an seperti sekarang ini, dapat mendorong generasi ini mengerti kandungan al-Qur'an?

Sungguh aneh, generasi tua sendiri telah meninggalkan alQur'an; namun ia menyesali generasi mudanya karena tidak mengenal al-Qur'an! Sungguh, kita sendirilah yang telah menjauh dari al-Qur'an, lalu mengharap generasi muda mendekat kepadanya! Mari dibuktikan, bagaimana al-Qur'an menjadi sesuatu yang ditinggalkan di antara kita. Jika seseorang diketahui sebagai pakar tentang al-Qur'an, yakni banyak melakukan penelitian dan perenungan tentang makna-makna yang terkandung di dalamnya; atau ia mempelajari tafsir al-Qur'an secara mendalam, sejauh apa ia dihormati di kalangan kita? Nihil!

Artikel ini tertarik untuk mengutip tulisan Muthahhari ini karena belum bisa baca Al-Qur'andan belum mampu menjadikannya sebagai pegangan hidup, yang kepadanya berkonsultasi setiap hari dalam menghadapi berbagai hal. Muthahhari menunjukkan lebih lengkap lagi dalam bukunya bahwa jauhnya generasi muda dari al-Qur'an karena orang-orang tua tidak menunjukkan apresiasi yang tinggi terhadap orang yang memiliki penguasaan bagus atas al-Qur'an.

Generasi muda mengambil semangat dari bagaimana orangtua mereka menyikapi segala sesuatu di sekeliling mereka. Ketika mereka mendapati orangtua kurang perhatian terhadap orang yang memiliki penguasaan al-Qur'an, memberi respon yang datar, dan tidak terdengar ucapan yang menyiratkan kecintaan, maka mereka tidak menaruh minat dan bahkan lebih jauh lagi dibanding orangtua mereka. Ini tidak berarti orangtua mereka tidak mengajarkan kepada mereka tentang al-Qur'an, tidak berarti orangtua mereka tidak membaca al-Qur'an, tidak berarti orangtua mereka jauh dari al-Qur'an, dan juga tidak berarti orangtua mereka tidak mencintai al-Qur'an. Tetapi kecintaan dan kedekatan mereka dengan al-Qur'an tidak dicerminkan dalam ucapan spontan dan sikap menghargai 
terhadap al-Qur'an dan orang-orang yang menguasainya, kecuali dalam bentuk ungkapan formal dalam pengajaran.

Contoh ungkapan formal ini adalah, "al-Qur'an adalah pegangan hidup setiap muslim. Setiap muslim harus mempunyai al-Qur'an." Ungkapan semacam ini tidak menggerakkan jiwa. Ungkapan ini lebih bersifat kognitif yang menjadi makanan bagi otak saja, tetapi tidak menghidupkan kehendak (konasi) dan rasa (afeksi). Padahal jika kehalusan perasaan dan kehendak bergerak (dzauq), pikiran juga ikut hidup, pikiran bekerja.

Bandingkan dengan ungkapan ketika mendengar rekan diterima di sebuah perusahaan otomotif. Apa yang dikatakan? Kita mengucapkan, "MasyaAllah, hebat ya. Wah, nanti besar sekali gajinya itu." Sangat lain efeknya terhadap perasaan antara kalimat pertama tadi dengan kalimat terakhir yang baru saja di dengar. Kalimat pertama lebih banyak bermuatan informasi dengan urutan logis: jika al-Qur'an penting, maka setiap orang perlu punya al-Qur'an. Sedang kalimat kedua secara langsung membangkitkan rasa kagum terhadap pekerjaan di perusahaan otomotif sekaligus menanamkan nilai bahwa letak kehebatan itu ada pada gaji.

Karena itu, orang pernah merasa risau ketika membaca sebuah buku panduan untuk ustadz/ustadzah TPA. Dalam buku itu dituliskan kalimat yang perlu diucapkan oleh seorang ustadz ketika menerangkan konsep tentang qadha dan qadar. Mari disimak cuplikan sekilas tentang qadar sambil merenungkan apakah itu sesuai untuk anak. Silakan periksa kalimat berikut ini: "Sekarang apa yang dimaksud dengan Qadar itu? Adapun yang dimaksud dengan Qadar adalah ketentuan-ketentuan Allah yang harus berlaku bagi setiap makhluk sesuai dengan batas ketentuan Allah yang telah diputuskan sejak zaman azali. Apakah hal tersebut berakibat baik atau buruk, segala sesuatunya telah ditentukan oleh Allah Swt."

Kalimat seperti itu tidak memiliki muatan perasaan, sehingga sulit menggerakkan jiwa dan membangkitkan perasaan terhadap kekuasaan Allah. Kalimat di atas lebih bersifat kognitif, hanya memberi informasi definisi qadar pada otak. Ditinjau dari segi tingkat abstraksinya, ${ }^{5}$ kalimat tersebut lebih sesuai untuk

${ }^{4}$ Pengurus TKA dan TPA Al-Ikhlas Bidang Kurikulum, Kumpulan Materi TKA: Aqidah, Akhlak dan Syari'ah (Yogyakarta : TKA dan TPA AlIkhlas Samirono, Catur Tunggal, 1997).

${ }^{5}$ Semakin tinggi tingkat abstraksi sebuah kalimat, semakin sulit orang membayangkan, semakin rendah tingkat abstraksinya semakin mudah orang 
mahasiswa daripada santri TKA. Penjelasan dengan kalimat yang membutuhkan kemampuan memahami konsep seperti pada kalimat di atas, dirasa lebih sesuai untuk mahasiswa Fakultas Ushuluddin jurusan Aqidah Filsafat dibanding anak usia TK atau SD. Ditinjau dari teori Jean Piaget tentang perkembangan kognitif, anak-anak usia TK belum mencapai tahap berpikir operasional formal. Dan menurut perkembangan taklif pun, mereka baru berkisar tahap tamyiz (membedakan benar salah dan baik buruk dengan kemampuan akalnya).

Barangkali merasa bingung dengan penjelasan ini lantaran dalam praktek pengajaran, anak-anak TKA menunjukkan respon dan mampu menanggapi ketika ditanya tentang pengertian qadar. Mereka dapat menyahut ketika ustadz mengucapkan kalimat yang memang sengaja tidak diselesaikan.

Mengenai persoalan tersebut, perlu menjelaskan dengan apa yang saya sebut sebagai pseudo-afektif (seolah-olah bersifat afektif). Guru dan orangtua sering merasa bahwa anak-anak antusias betul dan tanggap terhadap apa yang disampaikan ketika anak dengan cepat melengkapi kalimat yang tidak selesai. Guru (jugaorangtua) mengira, itu menunjukkan bahwa anak mampu menyerap materi yang diajarkan, sekalipun sulit. Padahal anak sesungguhnya hanya antusias untuk melengkapi kalimat dan tidak bersangkut paut dengan pemahaman dan penghayatan materi.

Kecepatan melengkapi kalimat lebih banyak berhubungan dengan daya ingat daripada pencerapan. Apalagi jika anak "belajar" dari orangtua bahwa pendengar harus segera merespon kata-kata yang terpenggal ketika seorang ustadz memberi ceramah.

Misalnya, anak melihat bagaimana ibunya selalu meneruskan kata-kata ustadz yang tidak selesai sekalipun tidak memperhatikan dengan sungguh-sungguh. Karena itu ketika di TKA ustadznya mengucapkan kalimat, "Jadi, ini merupakan takdir Al... All...?", maka ia segera menyahut, "Allah....!" artikel

membayangkan. Penggambaran tentang surga dalam Al-Qur'anmemakai kalimat yang mengandung nilai abstraksi rendah sehingga justru memungkinkan orang untuk membayang-bayangkan betapa indahnya surga yang di dalamnya ada bidadari-bidadari yang sebaya usianya dengan kita, yang selalu perawan dan penuh gairah, yang di bawahnya mengalir sungai-sungai susu, yang.... ah, bisakah kita mendapatkan surga-Nya? Setelah orang membayang-bayangkan betapa nikmatnya surga, kita diberi penjelasan dengan tingkat abstraksi yang tinggi. Sehingga insya-Allah justru membangkitkan rasa penasaran kita. Sebab segala keindahan yang sanggup kita bayangkan, ternyata masih tidak akan sanggup mewakili keindahan yang ada di surga. 
ini membicarakan bukan tentang komunikasi ustadzah TKA. Pembicaraan lebih jauh tentang kalimat yang mempunyai muatan perasaan, silakan untuk dianalisis kembali, referensi yang bisa digali misalnya Mutiara Ilmu Balaghah, terbitan Mutiara Ilmu, Surabaya.

Artikel ini membicarakan tentang kalimat yang menggerakkan jiwa, rasakan kalimat berikut. Ucapkan kepada anak yang mulai mengerti:

"Wahai Anakku, sesungguhnya aku akan mengajarkanmu beberapa kata ini sebagai nasehat buatmu. Jagalah hak-hak Allah, niscaya Allah pasti akan menjagamu. Jagalah dirimu dari berbuat dosa terhadap Allah, niscaya Allah akan selalu berada di hadapanmu. Apabila engkau menginginkan sesuatu, mintalah pada Allah. Dan apabila engkau menginginkan pertolongan, mintalah pertolongan pada Allah. Ketahuilah, bahwa apabila seluruh umat manusia berkumpul untuk memberi manfaat padamu, mereka tidak akan mampu melakukannya kecuali apa yang telah dituliskan oleh Allah di dalam takdirmu itu. Juga sebaliknya, apabila mereka berkumpul untuk mencelakai dirimu, niscaya mereka tidak akan mampu mencelakaimu sedikit pun kecuali atas kehendak Allah. Pena telah diangkat dan lembaran takdir telah kering. ",

Pembicaraan tentang pengaruh komunikasi suami-istri terhadap pendidikan anak masih panjang. Tetapi mengalami kesulitan dalam mengungkapkan secara tertulis karena sebagian lebih mengena untuk dibicarakan secara lisan daripada melalui tulisan. Pengungkapan secara lisan memungkinkan untuk mencontohkan secara gamblang, terutama yang bersangkut paut dengan cara bicara, ekspresi wajah, intonasi, dan perbedaan volume suara.

E. Pendidikan dengan Keteladanan

Menurut al-Ghazali anak adalah amanat bagi orang tuanya. Hatinya yang suci merupakan permata tak ternilai harganya, masih murni dan belum terbentuk. Orang tuanya

${ }^{6}$ Kalimat ini adalah nasehat Rasulullah kepada Ibnu 'Abbas. Ketika itu Ibnu 'Abbas masih kanak-kanak yang baru mengerti. Hadis ini diriwayatkan oleh At-Tirmidzi. Membandingkan materi panduan untuk ustadzah TKA dengan hadis Nabi memang tidak adil. Tapi saya tidak menemukan contoh yang lebih baik dibanding hadis ini. Ada contoh lain sebagaimana termuat pada buku Mendidik Anak Bersama Rasulullah karya Muhammad Nur Abdul Hafizh (Al-Bayan, 1997) hal.120. 
merupakan arsitek atau pengukir kepribadian anaknya. Sebelum mendidik orang lain, sebaiknya orang tua harus mendidik pada dirinya terlebih dahulu. Sebab anak merupakan peniru ulung. Segala informasi yang masuk pada diri anak, baik melalui penglihatan dan pendengaran dari orang di sekitamya, termasuk orang tua akan membentuk karakter anak tersebut. Apalagi anak yang berumur sekitar 3-6 tahun, ia senantiasa melakukan imitasi terhadap orang yang ia kagumi (ayah dan ibunya). Rasa imitasi dari anak yang begitu besar, sebaiknya membuat orang tua harus ekstra hati-hati dalam bertingkah laku, apalagi didepan anakanaknya.

Sekali orang tua ketahuan berbuat salah dihadapan anak, jangan berharap anak akan menurut apa yang diperintahkan. Oleh karena itu sudah sepantasnya bagi orang tua pemegang amanat, untuk memberikan teladan yang baik kepada putra-putrinya dalam kehidupan berkeluarga. Keluarga merupakan sekolah pertama bagi anak. Orang tua terutama ibu merupakan pendidik pertama dan utama bagi anak dalam membentuk pribadinya.

Ibu mempengaruhi anak melalui sifatnya yang menghangatkan, menumbuhkan rasa diterima, dan menanamkan rasa aman pada diri anak. Sedangkan ayah mempengaruhi anaknya melalui sifatnya yang mengembangkan kepribadian, menanamkan disiplin, memberikan arah dan dorongan serta bimbingan agar anak tambah berani dalam menghadapi kehidupan.

Teladan yang baik dari orang tua kepada anak (sekitar umur 6 tahun) akan berpengaruh besar kepada perkembangan anak di masa mendatang. Sebab kebaikan di waktu kanak-kanak awal menjadi dasar unluk pengembangan di masa dewasa kelak untuk itu lingkungan keluarga harus sebanyak mungkin memberikan keteladanan bagi anak. Dengan keteladanan akan memudahkan anak untuk menirunya. Sebab keteladanan lebih cepat mempengaruhi tingkah laku anak. Apa yang dilihatnya akan la tirukan dan lama kelamaan akan menjadi tradisi bagi anak.

1. Keteladanan dalam ibadah

2. Keteladanan bermurah hati

3. Keteladanan kerendahan hati.

4. Keteladanan kesantunan

5. Keteladanan keberanian

6. Keteladanan memegang akidah 
Karena obyeknya anak (kanak-kanak) tentunya bagi orang tua dalam memberikan teladan harus sesuai dengan perkembangannya sehingga anak mudah mencerna apa yang disampaikan oleh bapak ibunya. Sebagai contoh agar anak membiasakan diri dengan ucapan "salam", maka senantiasa orang tua harus memberikan ajaran tersebut setiap hari yaitu hendak pergi dan pulang ke rumah (keteladanan keiendahan hati), yang penting bagi orang tua tampil dihadapan anak sesuai dengan ajaran-ajaran Islam, niscaya semua itu akan ditirunya.

\section{F. Pendidikan dengan adat kebiasaan}

Setiap manusia yang dilahirkan membawa potensi, salah satunya berupa potensi beragama. Potensi beragama ini dapat terbentuk pada diri anak (manusia) melalui dua faktor, yaitu; faktor pendidikan Islam yang utama dan faktor pendidikan lingkungan yang baik. Faktor pendidikan Islam yang bertanggung jawab penuh adalah bapak ibunya. Ia merupakan pembentuk karakter anak.

\section{G. Pendidikan dengan Nasihat}

Pemberi nasihat seharusnya orang yang berwibawa di mata anak. Dan pemberi nasihat dalam keluarga tentunya orang tuanya sendiri selaku pendidik bagi anak. Anak akan mendengarkan nasihat tersebut, apabila pemberi nasihat juga bisa memberi keteladanan. Sebab nasihat saja tidak cukup bila tidak diikuti dengan keteladanan yang baik.

Anak tidak akan melaksanakan nasihat tersebut apabila didapatinya pemberi nasihat tersebut juga tidak melaksanakannya, anak tidak butuh segi teoritis saja, tapi segi praktislah yang akan mampu memberikan pengaruh bagi diri anak.

Nasihat yang berpengaruh, membuka jalannya ke dalam jiwa secara langsung melalui perasaan. Setiap manusia anak selalu membutuhkan nasihat, sebab dalam jiwa terdapat pembawaan itu biasanya tidak tetap, dan oleh karena itu kata-kata atau nasihat harus diulang-ulang. Nasihat akan berhasil atau mempengaruhi jiwa anak, tatkala orangtua mampu memberikan keadaan yang baik

\section{H. Pendidikan dengan Perhatian}

Sebagai orangtua berkewajiban untuk memenuhi kebutuhan-kebutuhan anaknya, baik kebutuhan jasmani ataupun 
kebutuhan yang berbentuk rohani, diantara kebutuhan anak yang bersifat rohani adalah anak ingin diperhatikan dalam perkembangan dan pertumbuhannya

Pendidikan dengan perhatian adalah mencurahkan, memperhatikan dan senantiasa mengikuti perkembangan anak dalam pembinaan akidah dan moral, persiapan spiritual dan sosial, disamping selalu bertanya tentang situasi pendidikan jasmani dan daya hasil ilmiahnya. Orang tua yang bijaksana tentunya mengetahui perkembangan-perkembangan anaknya dan ibu adalah pembentuk pribadi putra-putrinya lebih besar prosentasenya dibanding seorang ayah.

\section{Pendidikan dengan memberikan hukuman}

Hukuman diberikan, apabila metode-metode yang lain sudah tidak dapat merubah tingkah laku anak, atau dengan kata lain cara hukuman merupakan jalan terakhir yang ditempuh oleh pendidik, apabila ada perilaku anak yang tidak sesuai dengan ajaran Islam. Sebab hukuman merupakan tindakan tegas untuk mengembalikan persoalan di tempat yang benar. Hukuman sesungguhnya tidaklah mutlak diberikan. Karena ada orang dengan teladan dan nasehat saja sudah cukup, tidak menerapkan hukuman. Tetapi pribadi manusia tidak sama seluruhnya.

Sebenarnya tidak ada pendidik yang tidak sayang kepada siswanya. Demikian juga tidak ada orang tua yang merasa senang melihat penderitaan anaknya. Dengan memberikan hukuman orang tua sebenarnya merasa kasihan terhadap anaknya yang tidak mau melaksanakan ajaran Islam. Karena salah satu fungsi dan hukuman adalah mendidik. Sebelum anak mengerti peraturan, ia dapat belajar bahwa tindakan tertentu benar apabila tidak menerima hukuman dan tindakan lainnya salah apabila mendapatkan suatu hukuman.

\section{J. Penutup}

Dari penjelasan di atas, akhirnya artikel ini menyimpulkan, antara lain. Dalam surah Luqman ayat 13-19 tersebut sudah mencakup tiga aspek ajaran Islam, yaitu Aqidah, ibadah dan syari'ah. Pada Aspek pendidikan Aqidah meliputi halhal pokok yaitu: Pertama, keimanan (pengesaan) kepada Allah Swt, keyakinan tauhid yang sebersih-bersihnya yaitu larangan mensekutukan Allah, kesadaran akan kemakhlukan yang wajib mensyukuri segala karunia Tuhan. Kedua, kesadaran bahwa 
segala gerak-gerik yang nampak maupun yang tersembunyi tidak lepas dari pengetahuan dan pengawasan Tuhan.

Adapun aspek ibadah yang paling pokok adalah menyangkut masalah, yaitu ;

1) Perintah shalat, yaitu melaksanakan shalat fardu lima kali sehari, dan shalat nawafil lainnya.

2) Perintah amar ma'ruf, dalam pelaksanaannya pada anak-anak adalah anak-anak dibiasakan dalam berhubungan dengan manusia dengan mengerjakan amal-amal shaleh dan menyuruh orang lain melakukan kebaikan.

3) Perintah mencegah yang munkar, bagi anak prakteknya adalah ditanamkan kepada anak akan rasa benci dan tidak melakukan segala perbuatan yang munkar yaitu segala perbuatan yang bertentangan dengan agama.

4) Perintah melaksanakan kesabaran dalam menghadapi segala ujian, cobaan yang menimpanya.

5) Pada aspek pendidikan akhlak melipuli etika pergaulan yang baik yang perlu ditanamkan kepada anak, meliputi :

a) Bertutur kata yang lemah lembut dengan siapapun, terutama dengan orang tua.

b) Larangan berlaku sombong atau takabur dengan siapapun juga baik dalam berbicara (tidak memalingkan muka) maupun berjalan.

c) Berlaku sederhana dalam hidup dan kehidupannya.

\section{Daftar Pustaka}

Ahmad, Muhdlor, Etika dalam Islam, Surabaya : Al-Ikhlas,1988.

Al-Hasyimi, Muhammad Ali, The Ideal Muslimah the True Islamic Personality of The Muslim Woman as Defined in The Qur'an and sunnah. Terj. Fungky Kusnaedi Timur, "Muslimah Ideal pribadi Islami dalam al-Qur'an dan asSunnah", Yogyakarta : Mitra Pustaka, Cetakan I. 2000.

At-Tirmidzi, Sunan, al-Jami'us Sahih, Lebanon : Dar al-Kutbi, Juz IV, $\mathrm{t}, \mathrm{th}$

Daud, Abi, Sunan Abi Daud, Indonesia : Maktabah Dahlan, Juz I, t.th.

Depag Rl, al-Qur'an dan Terjemahannya, Semarang : Toha Putra, 1989.

Departemen Agama Rl, Proyek Pengembangan Kitab Suci Al Qur'an dan Terjemahannya, Jakarta: 1986/1987.

Hafizh, Muhammad Nur Abdul, Mendidik Anak Bersama Rasulullah, Al-Bayan, 1997. 
Hava Binti Mubarok al-Barik, Mausu'ah al-Mar'atul Muslimah, terj. Amir Hanuah Fachrudin, "Ensiklopedi Wanita Muslimah", Jakarta : Darul Falah, cet. IV, 1998.

Hurlock, Elizabeth B. t.t. Terj. Med.Meitasari Tjandrasa, "Perkembangan Anak", Jakarta: Erlangga, jilid II, 1999.

Kumpulan Materi TKA: Aqidah, Akhlak dan Syari'ah, TKA dan TPA Al-Ikhlas Samirono, Catur Tunggal, Yogyakarta, 1997.

lsawi, Abdurrahman, Anak dalam Keluarga, Jakarta, Studia Press, Edisi II, 1994.

Muhammad 'Ah Quthb, Auladima fi-Dlaw-u Tarbiyyatil Islamiyah, Terj. Bahrun Abu Bakar Ihsan, "Sang Anak dalam Naungan Pendidikan Islam", Bandung: Diponegoro, cet. II, 1993.

Mushoffa dan Imam Musbikin, Sepasang Burung dan Nabi Sulaiman, Yogyakarta. Mitra Pustaka, Cetakan 1, 2001.

Muslim, Imam, Sahih Muslim, juz IV, Lebanon ; Dar al-Kutbi alllmiah, th.

Quthb, Muhammad. t.t, Terj. Salman Harun "Sistem Pendidikan Islam", Bandung : Ma-arif, 1993.

Ulwan, Abdullah Nashih, Tarbiyatul Aulad fil-Islam, Terj Khalilullah Ahmas Masykur Hakim, "Pemeliharaan Kesehatan Jiwa Anak", Bandung : Remaja Rosdakarya, Cetakan kedua, 1992. 